УДК 379.823(477.83)«1944/1958»

DOI: $10.24919 / 2519-058 \times .6 .123752$

\begin{abstract}
Марія ВУРЛОВСЬКА,
orcid.org/0000-0003-1520-3348

аспірант кафедри всесвітньої історії та спеціальних історичних дисциплін

Дрогобииького державного педагогічного

університету імені Івана Франка

(Україна, Дрогобич) marya_vurlovska@ukr.net
\end{abstract}

\title{
РАДІО У ПОВСЯКДЕННОМУ ЖИТТІ МЕШКАНЦІВ ДРОГОБИЧЧИНИ (1944 - 1958)
}

\begin{abstract}
У статті розглянуто значення радіо у повсякденні населення Дрогобиччини у післявоєнний період. Показано, щзо радянська система розглядала радіо як важливий ідеологічний інструмент. Досліджено, щьо радіо урізноманітнювало дозвілля населення, було засобом отримання відомостей про події в СРСР та світі $і$ чи не єдиною можливістю дізнатися альтернативні джерела інформації із закордону.

Ключові слова: Дрогобиччина, радіо, радіотранслячія, радіопередачі, дозвілля, ідеологізачія, повсякдення.
\end{abstract}

Mariia VURLOVS'KA, Postgraduate Student of Department World History and Special Historical Disciplines, Drohobych Ivan Franko State Pedagogical University (Ukraine,Drohobych) marya_vurlovska@ukr.net

\section{RADIO IN EVERYDAY LIFE OF THE INHABITANTS OF DROHOBYCH LAND (1944 - 1958)}

The post-war years manifested a special period of peace life revival after military actions. The study of the role of radio in daily life of the population of the Drohobych land will help to better understand the post-war period and life of ordinary people at this time. Radio influence on everyday life of average men is the main problem of the given article.

The Soviet system considered radio as an important ideological instrument. By radio propaganda lectures were read. Spreading of Soviet ideology amongst all levels of population was the pivotal problem of radio. From mid 1950s radio was means of influencing the population in order to encourage people to leave their native land and go to plough virgin lands of Kazakhstan. Radio informed the people about party and Komsomol life, industry and agriculture development in the region. Besides, by radio musical concerts and theatrical performances were broadcast.

Also, radio announced advertisements. Advertising by radio purposed to inform listeners of the information on the sale of some or other goods. From radio announcements the inhabitants also learnt about theatrical performance and film sessions which were to take place at local theatres and cinemas.

The use of radio was chargeable. All owners of radio sets paid for their use 5, 54 or 75 roubles monthly. All radio receivers should have undergone registration and unauthorized connection to the radio network was forbidden.

The population distrusted the Soviet radio. People listened to foreign radio stations, such as «BBC», «The Voice of America», "The Voice of Israel», "Vilna Yevropa / Free Europe», and "Vatican Radio». Their collective hearings, despite jammimg of foreign broadcasting in the USSR, were often organised.

The radio worked with faults through electric power breakages, poor-quality repair, and line damages. However, people had to pay for using even defective radio.

The article proves that radio diversified the leisure time of the population of Drohobych land. Thanks to radio in the post-war years local ordinary inhabitants learnt the latest news, listened to musical concerts and broadcasts. Radiofication was rapidly carried out by the Soviet power, but it was not always successful and qualitative. On the one hand, the Soviet management assigned to radio an important function of propaganda influence, but on the other hand radio, contrarily, became a unique possibility for population to hear foreign news, programmes, including those of religious character. Despite attempts to dampen foreign radio-waves, the Soviets did not manage to do it full measure. During the post-war period, radio had a great 
influence on everyday life of average people which can be compared with that of contemporary television and the Internet.

Key words: Drohobych land, radio, broadcasting, radio programs, leisure, ideologization, daily live.

Мария ВУРЛОВСКАЯ, аспирант кафедры всемирной истории и специальных исторических дисииплин

Дрогобычского государственного педагогического университета имени Ивана Франко (Украина, Дрогобыч) marya_vurlovska@ukr.net

\section{РАДИО В ПОВСЕДНЕВНОЙ ЖИЗНИ ЖИТЕЛЕЙ ДРОГОБЫЧСКОГО РЕГИОНА (1944 - 1958)}

В статье рассмотрено значение радио в повседневной жизни населения Дрогобычской области в послевоенный период. Показано, что советская система рассматривала радио важным идеологическим инструментом. Доказано, что радио разнообразило досуг населения, было средством получения сведений о событиях в СССР и мире и едва ли не единственной возможностью узнать альтернативные источники информации из-за границьл.

Ключевые слова: Дрогобычская область, радио, радиотрансляиия, радиопередачи, досуг, повседневность.

Постановка проблеми. Повоєнні роки були особливим періодом відродження мирного життя. Завершення війни та встановлення радянської влади у регіоні стали «великими» змінами у буденному житті «маленьких» людей. Щоб наблизитися до глибшого розуміння означеної епохи, потрібно вивчити історичний досвід пересічних людей, які зазвичай не викликали зацікавлення у дослідників. Важливо повернутися від розуміння людини як об’єкта історії, до ії розгляду як суб'єкта та творця минулого. Вивчення ролі радіо у повсякденні населення Дрогобицької області допоможе краще зрозуміти повоєнний період і буденне життя населення краю у цей час.

Аналіз досліджень. Історія повсякдення різних груп населення радянської України у післявоєнний період подана в колективній монографії «Повоєнна Україна: нариси соціальної історії (друга половина 1940-х - середина 1950-х рр.)» (Даниленко, 2010: 336). Різні аспекти історії післявоєнного радіо в УРСР подані у наукових доробках Ю. Колісник, В. Клювака, В. Шапоренка (Колісник, 2014: 39-46; Клювак, 2011: 273-292; Шапоренко, 2013: 67). Важливими історичними джерелами для вивчення місця радіо у повсякденні населення Дрогобиччини є спогади та приватне листування. Окремих досліджень, які б стосувалися впливу радіо на повсякденне життя населення Дрогобицької області, наразі немає.

Мета статті - показати роль радіо у повсякденному житті населення Дрогобиччини у післявоєнний період.

Виклад основного матеріалу. Більшовицька партія та радянський уряд великого значення надавали справі радіофікації країни, аргументуючи це потребою задоволення культурних запитів народу. А насправді ж це був дієвий спосіб інформаційного впливу на населення, особливо в західних областях України, де знову відновлювався сталінський режим. «Радіо у нас служить могутнім засобом комуністичного виховання широких мас трудящих», - зазначалося у газеті «Радянське слово» (Радіо - в кожну колгоспну хату. Радянське слово. 1951. 25 грудня. С. 2). Місцеве радіомовлення здійснювали республіканські, обласні та міські радіокомітети і радіоредакції. Технічна база радіомовлення була слабкою, тому швидкими темпами відновлювалися радіовузли. Цей процес був на контролі партійно-державних органів. У другій половині 1940-х рр. в Дрогобицькій області щомісяця встановлювали від 150 до 350 радіоточок (ДАЛО. Ф. 5001. Оп. 7. Спр. 118. Арк. 14). У містах після війни радіо з'явилося у квартирах, гуртожитках, лікарнях, дитячих садках, клубах, кінотеатрах, на підприємствах (Дирекція радіотрансляційної мережі Дрогобицької області повідомляє. Радянське слово. 25 липня. 1946. С. 8). У 1948 р. у Дрогобицькій області діяло 2985 радіоточок, а в 1951 р. - близько 18 000, з них 4500 - у квартирах (ДАЛО. Ф. 5001. Оп. 10. Спр. 123. Арк. 2). У цьому ж році працювало 34 радіовузли, від яких було радіофіковано 152 населені пункти (Велика благородна справа. Радянське слово. 1951. 6 травня. С. 3). Спеціальним 
розпорядженням партійного керівництва у перші повоєнні роки радіоприймачі винятково спочатку виключно для секретарів обкомів, райкомів партії і комсомолу (Ісайкіна, 2010: 182).

Швидкими темпами радіо, яке вважалося «вісником достатку та культури колгоспників» підключали у села (Говорить Москва. Радянське слово. 6 травня. 1951. С. 3). У 1951 р. у Самбірському районі зі 510 встановлених радіоточок 490 були у селах (Велика благородна справа. Радянське слово. 1951. 6 травня. С. 3). У цьому ж році у с. Бортники Ходорівського району був збудований міжколгоспний радіовузол потужністю 500 ват, який обслуговував близько 350 радіоточок. Також будувалися радіовузли на 1000 точок у селах Старява Хирівського району, Матків Боринського району, Монастирець Самбірського району. Для прикладу, в обласному центрі радіовузол обслуговував десять тисяч радіоточок (Радіо - в кожну колгоспну хату. Радянське слово. 1951. 25 грудня. С. 2).

Офіційна преса повідомляла про неабияке задоволення населення від можливості слухати радіо: «За роки радянської влади в культурному житті трудящих Дрогобиччини сталися великі зміни... Невпізнанно змінилося село. В хаті колгоспника засвітилася лампочка Ілліча. 3 репродукторів чути голос рідної Москви, Києва та інших міст нашої країни. Радіо входить у побут кожного трудящого» (Велика благородна справа. Радянське слово. 1951. 6 травня. С. 3). У газеті часто писалося, що після трудового дня селяни збираються разом, спільно слухають радіопередачі та жваво обговорюють почуті новини: «Коли почав працювати радіовузол, їздовий колгоспу Дмитро Матвіїв сказав: «Тепер у моїй хаті стало веселіше, радісніше. Вся моя родина слухає передачі з Москви і Києва» (Говорить Москва. Радянське слово. 6 травня. 1951. С. 3). Часто такого типу інформація підкріплювалася колективними фотографіями. 3 газетних повідомлень дізнаємося також, що з перших днів будівництва радіовузла в с. Бортники Ходорівського району хлібороби виявили велику зацікавленість до нього. «Сто репродукторів, які закупила артіль, були розібрані буквально за одну годину» (Говорить Москва. Радянське слово. 6 травня. 1951. С. 3; Радіофікація сіл. Радянське слово. 12 січня. 1951. С. 3). У селах основним місцем, де слухали радіо, був сільський клуб (ДАЛО. Ф. 5001. Оп. 17. Спр. 150. Арк. 99). Теодозія Стебівка, жителька села В. Висоцьке Турківського району, у листі до доньки (1955) писала: «в кожній хаті є радіо і ми теж маємо. А світла ще нема, бо не можемо все заплатити» (Лист Теодозії Стебівки, 1955 p. Приватний архів Івана Стебівки у м. Дрогобич).

Незважаючи на те, що радіофікація вважалася важливою державною справою, на початку 1950-х рр. нерадіофікованими залишалися цілі райони області. У 1951 р. у Миколаївському районі не було радіофіковане жодне село (Радіо - в кожну колгоспну хату. Радянське слово. 1951. 25 грудня. С. 2). Радіовузли працювали з перебоями, через нестачу електроенергії, відсутність палива (Чому Бортницький радіовузол працює з перебоями? Радянське слово. 4 січня. 1952. С. 3.; ДАЛО. Ф. 5001. Оп. 15. Спр. 173. Арк. 72; ДАЛО. Ф. 5001. Оп. 7. Спр. 118. Арк. 4-5). Сільські жителі часто скаржилися, що гучномовці та репродуктори не працювали протягом тривалого часу (інколи й цілий рік), при цьому працівники районного радіовузла не реагували на їхні скарги (Короткі сигнали Радянське слово 19 січня. 1958. С. 2). А за несправне радіо селяни все ж змушені були платити (Короткі сигнали. Радянське слово. 3 жовтня. 1956. С. 3).

Жителі села Журавно обурювалися тим, що радіо працювало з перебоями, розпочинало свою роботу о 7 годині ранку та завершувало у 9 годині вечора (Ні радіо, ні газет. Радянське слово. 16 червня. 1946. С. 5). Жителі с. Бортники Ходорівського району скаржилися, що радіовузол у селі обслуговував тільки шість сіл, але його потужність дозволяла обслуговувати більше - 8 сіл або 1700 радіоточок, а мешканці села Нижанковичі писали до обласної газети, що «місцевий радіовузол транслює дуже нерегулярно - раз на тиждень, а коли і ще гірше» (Короткі сигнали. Радянське слово. 4 грудня. 1956. С. 4). У деяких селах «ніяк не спроможуться встановити розетки» (Чому Бортницький радіовузол працює з перебоями? Радянське слово. 4 січня. 1952. С. 3).

Мали місце зловживання щодо державних коштів, які виділялися на радіофікацію області. У Кропивнику Добромильського району витрати на радіофікацію села становили близько чотирьох тисяч крб., а радіоточок встановили лише сімнадцять. В селі Антиновка Журавнівського району вартість виконаних робіт складала одинадцять тисяч крб., а радіо було лише в 9 хатах» (Радіо - в кожну колгоспну хату. Радянське слово. 1951. 25 грудня. С. 2). 
У цей час з'являється нова професія - радіотехнік (Говорить Москва. Радянське слово. 6 травня. 1951. С. 3). При призначенні радіотехніків на роботу перевагу надавали членам партії (ДАЛО. Ф. 5001. Оп. 10. Спр. 123. Арк. 2). До прокладання радіоліній, копання ям, підвезення стовпів була залучена молодь, представники партійних та комсомольських організацій (Радіо - в кожну колгоспну хату. Радянське слово. 1951. 25 грудня. С. 2). «Монтери радіовузлів працювали з раннього ранку та до пізнього вечора», - зазначалося у газеті «Радянське слово» (Говорить Москва. Радянське слово. 6 травня. 1951. С. 3). У 1955 р. Марія Стебівка, жителька с. В. Висоцьке Турківського району, пише у своєму листі про свого чоловіка-радіотехніка: «його вдома нема вже третій тиждень. Роблять нову лінію на радіо» (Лист Марії Стебівки, 1955 р. Приватний архів Івана Стебівки у м. Дрогобич).

До радіотехнічних знань молодь зацікавлювали гуртки радіоаматорів (Велика благородна справа. Радянське слово. 1951. 6 травня. С. 3). У Дрогобицькому електромеханічному технікумі діяв гурток радистів-модераторів, якими керували студенти другого курсу (Гурток радистів-операторів. Радянське слово. 10 січня. 1951. С. 2).

Радіо ставало звичним явищем у повсякденні населення Дрогобиччини. За його користування потрібно було плати у поштових відділеннях, і оплата стягувалася за цілий рік (Дрогобицьке обласне управління зв'язку доводить до відома. Радянське слово. 26 грудня. 1958. С. 4; до відома власників радіоприймачів. Радянське слово. 1951. 19 грудня. С. 4). Плата за детекторний радіоприймач, який не потребував зовнішнього джерела живлення, складала 5 крб. Вона була доступною для пересічного дрогобичанина. Абонплата за радіоприймачі в окремих кімнатах і загальних кімнатах гуртожитків становила 36 крб., за радіоприймачі в червоних кутках, в читальнях, аудиторіях 54 крб., 75 крб. коштувало радіо на підприємствах, установах, організаціях, навчальних та медичних закладах, літаках, поїздах та автомашинах (До відома власників радіоприймачів. Радянське слово. 1951. 19 грудня. С. 4). Щоб не платити, дехто ухитрявся самовільно підключатися до радіомережі (ДАЛО. Ф. 5001. Оп. 10. Спр. 123. Арк. 2). У період $з$ травня до червня 1948 р. на Стрийському радіовузлі було списано 217 фіктивних радіоточок, на Бориславському - 195, на Ходорівському - 44 (Дирекція радіотрансляційної мережі Дрогобицької області повідомляє. Радянське слово. 25 липня. 1946. С. 8).

3 метою обліку і контролю з боку партійного керівництва усі радіоприймачі - лампові і детекторні - підлягали обов'язковій реєстрації. У разі виявлення незареєстрованого радіоприймача на їхніх власників накладався штраф (До відома власників радіоприймачів. Радянське слово. 1951. 19 грудня. С. 4; Дрогобицьке обласне управління зв'язку доводить до відома. Радянське слово. 26 грудня. 1958. С. 4). Визначалися і терміни реєстрації. На початку 1950-х рр. жителі Дрогобича та районних центрів зобов'язувалися зареєструвати радіоприймач протягом трьох днів з моменту його придбання, мешканці інших місцевостей - протягом десяти днів (Дрогобицьке обласне управління міністерства зв'язку доводить до відома власників радіоприймачів. Радянське слово. 6 листопада. 1953. С. 4). Уже в кінці 1950-х рр. термін реєстрації радіо та телевізорів був дещо збільшений - не пізніше ніж через 20 днів 3 дня придбання (Дрогобицьке обласне управління зв’язку доводить до відома. Радянське слово. 26 грудня. 1958. С. 4).

Радіотрансляція розпочиналася у 6 годині ранку зі звуків Кремлівських курантів та гімну СРСР. «Говорить Москва. Добрий ранок, товариші! - чути з репродукторів (Говорить Москва. Радянське слово. 6 травня. 1951. С. 3). Кожного ранку на хвилі 320,8 метра мешканці регіону могли почути Дрогобицьке обласне радіо. Обласні новини та радіопередачі транслювали усі районні та сільські радіовузли (Короткі сигнали. Радянське слово. 4 грудня. 1956. С. 4).

Найголовнішими завданням радіо було поширення ідеології КПРС, пропаганда «політики партії і уряду» серед усіх верств населення. Цій меті служило більшість тогочасних радіопередач, призначених усім віковим, соціальним, професійним і національним групам населення (Клювак, 2011: 282). 3 метою пропагандистського впливу при Дрогобицькому облрадіокомітеті працював радіолекторій. Тематика лекцій говорить сама за себе: «Про трудове виховання дітей у сім'ї», «Класи і класова боротьба», «Про російське класичне образотворче мистецтво», «Київська Русь колиска трьох братніх народів», «Герой нашого часу» (ДАЛО. Ф. 5001. Оп. 10. Спр. 123. Арк. 9). Щоб радіо було «ніби своїм», зрозумілим, а основне - дієвим у формуванні масової радянської 
свідомості, крім виступів партійно-радянських діячів, які ділилися досвідом «агітмасової роботи серед трудящих» та розповідали про «прийом до партії і комсомолу кращих людей підприємств i заводів», обов'язковими були промови передовиків виробництва, місцевої інтелігенції, студентів, школярів (ДАЛО. Ф. 5001. Оп. 10. Спр. 123. Арк. 46). Щосуботи організовувалися комсомольські молодіжні випуски. У середині 1950-х рр. активно заохочували молодь їхати на цілину. Патріотичний дух піднімали трансляцією популярних пісень: «Їдемо ми, друзі, у далекі краї» (Спогади Софіяника Мирона Івановича, жителя м. Стрий Львівської області. Записала Марія Вурловська 09.01.2017 р. у с. Гаї Верхні. Приватний архів Марії Вурловської у м. Дрогобич).

Тематика радіоповідомлень була однаковою для всіх тодішніх засобів масової інформації. Населення Дрогобиччини слухало про радість возз'єднання у великій радянській сім’і, про злочини «українських буржуазних націоналістів», про досягнення колгоспного будівництва, розвиток промисловості в області, передвиборну агітацію. Кожен по-різному сприймав подану інформацію. Малоцікавими були офіційні повідомлення, популярними - трансляції музичних концертів, театральних вистав, зустрічей з відомими людьми (ДАЛО. Ф. 5001. Оп. 10. Спр. 123. Арк. 89; Спогади Чигиринського Івана Андрійовича, жителя м. Дрогобич Львівської області. Записала Марія Вурловська 10.11.2017 р. у м. Дрогобич. Приватний архів Марії Вурловської у м. Дрогобич). Радіо було комунікативним засобом, почуте по ньому передавалося, було предметом обговорень у колективах, окремих родинах, ставало способом поширення чуток, брехні на побутовому рівні. Дуже часто до жінок, які полюбляли поширювати плітки? говорили, що вони як «сільське радіо».

Корисними для людей були рекламні радіооголошення. Е них повідомлялося про продаж тих чи пих товарів, проведення громадських заходів, про те, що, коли і де можна побачити, 3 ким зустрітися (Шапоренко, 2013: 67; ДАЛО. Ф. 5001. Оп. 7. Спр. 121. Арк. 6). Текст радянського рекламного оголошення нагадував друковану рекламу, а до та після нього включались довгі музичні фрагменти (Шапоренко, 2013: 67). Доказом того, що населення критично ставилося до інформації, яку чуло по радіо, $є$ те, що воно навіть отримало народну назву - «брехунець» (Спогади Софіяника Мирона Івановича, жителя м. Стрий Львівської області. Записала Марія Вурловська 09.01.2017 р. у с. Гаї Верхні. Приватний архів Марії Вурловської у м. Дрогобич).

Через недовіру до радянського радіо населення шукало альтернативні джерела інформації. Незважаючи на заборону і покарання за «антирадянську пропаганду і агітацію», заглушування радянськими спецслужбами, люди слухали закордонні радіостанції, такі як «Бі-бі-сі», «Голос Америки», «Голос Ізраїлю», «Вільна Європа», радіо Ватикане (Даниленко, 2010: 22-23). Зарубіжне радіомовлення у СРСР заглушували за допомогою згенерованого електронного шуму. На це витрачалися значні державні кошти, про що свідчить стрімке зростання потужностей. Якщо у 1946 р. глушіння в СРСР здійснювалося всього через кілька десятків короткохвильових передавачів, то у 1956 р. їхня кількість сягнула 3000 (Колісник, 2014: 40). Але повністю перекрити доступ населенню до зарубіжних радіостанцій влада не могла (Даниленко, 2010: 22-23).

Релігійні радіотрансляції із закордону були єдиною можливістю збереження та підтримання релігійних традицій населення. Ярослав Возний, корінний житель м. Дрогобич, згадує: «У 1957 році, коли я був у 7 класі, я пішов на свою першу роботу. Із зароблених грошей я купив маленьке радіо. Радості не було меж. Ми «злапали» релігійну програму «Монтекарло» і іiї слухали. А вже потім я дізнався про діяльність підпільної УГКЦ та став іiї учасником» (Спогади Возного Ярослава Івановича, жителя м. Дрогобич Львівської області. Записала Марія Вурловська 04.05.2017 р. у м. Дрогобич. Приватний архів Марії Вурловської у м. Дрогобич).

Висновки. Завдяки радіо у повоєнні роки пересічні мешканці регіону дізнавалися свіжі новини, слухали музичні концерти та радіопередачі. Радіофікація регіону проводилася радянською владою швидкими темпами, але не завжди вдало та якісно. 3 одного боку радянське керівництво покладало на радіо важливу функцію пропагандистського впливу, але з іншого - воно, навпаки, стало унікальною можливістю для населення почути закордонні вісті, передачі, у т.ч. релігійного характеру. Незважаючи на заглушування закордонних радіохвиль, повністю це зробити так і не вдалося. У післявоєнний період радіо мало великий вплив на буденне життя звичайних людей, який можна прирівняти до сучасних телевізорів та інтернету. 


\section{СПИСОК ВИКОРИСТАНИХ ДЖЕРЕЛ И ЛІТЕРАТУРИ}

Газета «Радянське слово».

ДАЛО - Державний архів Львівської області.

Даниленко, 2010 - Даниленко В. Повоєнна Україна: нариси соціальної історії (друга половина 1940-х середина 1950-х рр.): колективна монографія. Київ, 2010. 336 с.

Ісайкіна, 2010 - Ісайкіна О. Історія повсякденності: теорія та практика // Матеріали Всеукр. наук. конф., Переяслав-Хмельницький, 14-15 трав. 2010. С. 181-184.

Клювак, 2011 - Клюквак В. 3 історії львівського обласного радіо та радіожурналістики у 20-х - 70-х роках ХХ століття // Теле- та радіожурналістика. 2011. №. 10. С. 273-292.

Колісник, 2014 - Колісник Ю. Радіозаглушування - невід'ємний складник радянської цензури, його роль у трансформації інформаційного протору // Вісник Львівського університету. Сер.: журналістика. 2014. № 39. С. 39-46.

Листування. 1955 р. Приватний архів Івана Стебівки у м. Дрогобичі.

Спогади. Приватний архів Марії Вурловської у м. Дрогобичі.

Шапоренко, 2013 - Шапоренко В. Жанрова система української радіореклами: етапи розвитку // Вісник Харківського національного університету імені В. Н. Каразіна. Сер.: Соціальні комунікації. 2013. № 1074. C. $66-70$.

\section{REFERENCES}

Hazeta «Radianske slovo» [«The Soviet Word»]. [in Ukrainian].

DALO - Derzhavnyi arkhiv Lvivskoi oblasti [State Archive of Lviv Region.]. [in Ukrainian].

Danylenko, 2010 - Danylenko V. Povoienna Ukraina: narysy sotsialnoi istorii (druha polovyna 1940-kh - seredyna 1950-kh rr.). [Postwar Ukraine: Essays on Social History (second half of 1940s - mid-1950's)]. 2010, 336 p. [in Ukrainian]. [in Ukrainian].

Isaikina, 2010 - Isaikina O. Istoriia povsiakdennosti: teoriia ta praktyka [The History of Everyday Life: Theory and Practice]. Materials of the All-Ukrainian Scientific Conference, 2010, pp. 181-184. [in Ukrainian].

Kliuvak, 2011 - Kliukvak V. Z istorii lvivskoho oblasnoho radio ta radiozhurnalistyky u 20-kh - 70-kh rokakh KhKh stolittia [From the History of Lviv Oblast Radio and Radio Journalism in 20th - 70th of XX Century]. TV and radio journalism, 2011, Nr 10, pp. 273-292. [in Ukrainian].

Kolisnyk, 2014 - Kolisnyk Yu. Radiozahlushuvannia - nevidiemnyi skladnyk radianskoi tsenzury, yoho rol u transformatsii informatsiinoho protoru [Radio Jamming - an Important Component of Soviet Censorship, its Role in Transforming of the Information Space]. Visnyk of the Lviv University. Series: Journalism. 2014, Nr 39, pp. $39-46$. [in Ukrainian].

Lystuvannia. 1955. Pryvatnyi arkhiv Ivana Stebivky u m. Drohobychi. [in Ukrainian].

Spohady. Pryvatnyi arkhiv Marii Vurlovskoi u m. Drohobychi. [in Ukrainian].

Shaporenko, 2013 - Shaporenko V. Zhanrova systema ukrainskoi radioreklamy: etapy rozvytku [Genre system of the Ukrainian radio advertizing: development stages]. Journal of V.N. Karazin Kharkiv National University. Series: Social Communications, 2013, Nr 1074, pp. 66-70. [in Ukrainian].

Стаття надійшла до редакиіï 2.02.2018 р. 